\title{
IMPACT OF THE URUGUAYAN Conditional Cash Transfer Program*
}

\author{
FERnANDO BorRaZ \\ Universidad de Montevideo \\ NiCOLÁs GONZÁLEZ \\ Universidad de Montevideo
}

\begin{abstract}
We analyze the impact of conditional cash payments on school enrollment, child labor and labor supply implemented between 2005 and 2007 to the poorest Uruguayan households. Targeting income discontinuities are not observed around the thresholds to participate in the program and this result invalidates the use of regression discontinuity designs for evaluating causal effects of the intervention. We apply the propensity score matching estimator to account for the endogeneity of program participation. We find that the program has no impact on school attendance but reduces female child labor in Montevideo. In addition negative effects are detected on the labor market in the rest of the urban areas.
\end{abstract}

JEL: I38, J22, H31

Keywords: Conditional Cash Transfer Program, Targeting Method, Propensity Score Matching

\section{INTRODUCTION}

Since the nineties conditional cash transfer programs (CCTs) have become one of the main tools of social protection in most Latin American and Caribbean countries. Despite differences in political and socioeconomic realities, CCTs are in the development agenda of almost all of them with similar designs. This kind of social policy is targeted towards families living in extreme poverty in order to alleviate poverty in the short term and increase investment in human capital

\footnotetext{
* We thank Susan Pozo, Verónica Amarante and Andrea Vigorito for discussion and suggestions. We also wish to thank participants at the conference "Making Impact Evaluations of Social Programs Work" organized by the Inter-American Conference on Social Security, the Universidad Iberoamericana, the Consejo Nacional de Evaluación de la Política de Desarrollo Social and UNDP Mexico, in Mexico DF, February 12, 2009. All errors are ours.

Email: fborraz@um.edu.uy
} 
of the families in the long term. For this reason, these programs link safety nets directly to human capital development by making the transfer conditional on school attendance and regular health care. The main objective of a CCT program is to reduce intergenerational transmission of poverty. At the same time, it tries to avoid negative effects on the labor market and benefit dependence.

In Uruguay, the CCT program-Ingreso Ciudadano-was the most important component of the National Emergency Plan (PANES) ${ }^{1}$, implemented between April 2005 and December 2007. This program attempted to reduce high poverty rates and indigence evidenced in the socio-economic indicators released by the National Statistical Office (INE). Though indigence and poverty incidence grew abruptly as a consequence of the economic crisis of 2002, it is necessary to emphasize that it is not the first time that these indicators revealed high levels of poverty (see Figure 1).

FIGURE 1

POVERTY AND INDIGENCE IN URUGUAY

$(1986-2006, \%)$

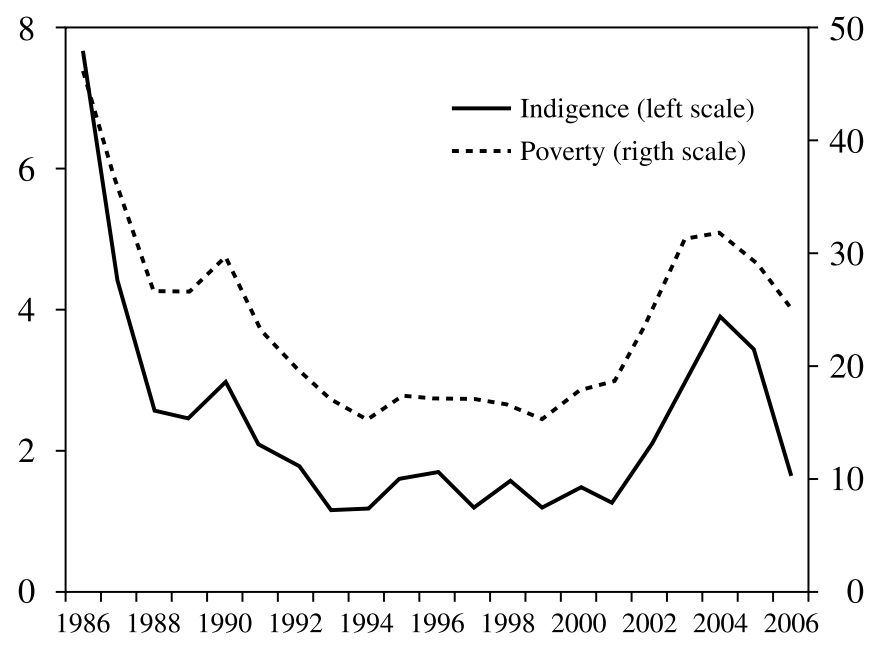

Source: Beltrami (2002); Amarante and Vigorito (2006).

However, the more recent period is characterized by the increases in three measures: i) child poverty, ii) poverty severity and social exclusion (lack of access to information, education, health care, or political power) iii) visibility of indigence '(De Armas, 2004). Moreover, in 2002 the indicator of income distribution (Gini index) reports the highest level of income concentration during the 1997-2002 period '(Bucheli and Furtado, 2004). The increased inequality is related to changes in the labor market that took place in the nineties, which increased the wage gap between

1 Ingreso Ciudadano represented the $68 \%$ of the National Emergency Plan budget. 
high-skilled and low-skilled workers. These structural changes contributed to extreme poverty. Therefore, the state of "social emergency" was not only due to growth in poverty and indigence, but also more difficulties to mitigate them. In this context, the Ingreso Ciudadano program could be considered as the first step to alleviate, and as far as possible, eradicate situations of extreme poverty in Uruguay.

The evaluation of this program is an essential component of the program agenda since it can improve policies by suggesting a more efficient use of limited fiscal resources. Impact evaluations experiences in Latin American and Caribbean countries have show that CCT programs constitute effective mechanisms to promote the access and use of education and health services among the poorest, as well as reducing poverty in the short term. But it is yet not clear whether these initiatives have enough capacity to reduce poverty in the medium term and to break poverty reproduction in the long term (Rawlings and Rubio, 2003)'.

We study the impact of the Uruguayan CCT program on school attendance, child labor and labor supply using the annual Uruguayan national household survey, (ECH). We estimate the impact of the Ingreso Ciudadano program in 2006 and 2007 separately. Despite the fact that this survey is not specifically created for the evaluation of the Ingreso Ciudadano program, it has the advantage over data collected by the ministry in charge of the program (MIDES) of being tainted by the desire of respondents to adopt strategic behavior in order to obtain the monetary benefit. The respondents, (not a public source of information), have the incentive to under report their income to increase the probability of being accepted into the program.

The MIDES data are inferior for yet another reason, because it is impossible to observe the results obtained by the households that have not taken part to the program. To get an efficient assessment of the program, we need a control group that can be compared with the treated group (experimental techniques). This could enable us to measure the real impact of the program ${ }^{2}$. In this case, giving the fact that treatment is not randomly assigned it is not possible to apply a natural experiment design to evaluate the impact of this program. Therefore, quasi-experimental methods like Regression Discontinuity (RD) and Propensity Score Matching methods (PSM) should be used. The application of the RD design requires that the assignment to the treatment be determined at least partly by the value of an observed variable to be above to a fixed threshold. It also requires the rigorous application of the eligibility criteria. In this program, the targeting method consists of an upper per capita income bound and a Critical Lack Index, CLI (Índice de Carencias Críticas). The household with a low per capita income (determined by law) and with a CLI higher than the fixed threshold established by the authorities could enter the program. If these criteria were fulfilled, we should observe a discontinuity in the probability of receiving the treatment surrounding the established threshold for the CLI.

However, discontinuity is not observed surrounding the thresholds of access to the program. This result invalidates the estimation of the impact using RD designs

2 This kind of experimental design was done in the CCT programs of Mexico '( 2005) and Nicaragua (Barham and Gitter, 2008). 
for evaluating causal effects of the intervention. The reasons for not reaching the threshold have to be the object of further research. We introduce some possible explanations: lack of appropriate communication between MIDES and the potential treatment group; lack of interest on the part of the household because of the risk of being stigmatized in society; administrative and operative difficulties of MIDES in determining the socioeconomic condition of the potential beneficiaries; etc.

Using PSM, we find that the program has not had significant effects on children school attendance but has had an effect (a reduction) in female child labor in Montevideo. In addition, negative effects have been detected in the labor market, mainly on women's labor supply in urban areas outside of Montevideo where more than $70 \%$ of the beneficiaries reside. To check the robustness of the result observed in the labor market, we estimate the impact of the program on labor supply using the National Household Survey of 2007. We find similar results to the 2006 findings. The absence of positive effects on children's school attendance can be explained by the close to universal levels of primary school attendance.

Our work is linked to the expanding literature that quantifies the impact of CCTs. 'Cardoso and Portela (2004) and Bourguignon et al. (2003)' find a strong effect of the Brazilian Bolsa Escola program on school attendance. Cardoso and Portela (2004) find that Bolsa Escola has no impact on child labor. Schultz (2004), Behrman et al. (2000, 2001 and 2005) and Skoufias and Parker (2001) conclude that the Mexican program PROGRESA increased the enrolment and attendance rate of poor children. Additionally there is no effect on achievement test scores

Attanasio et al. (2005) find that the Colombian programme Familias en Acción increase the attendance of children aged 12-17 years old and has no effect on school attendance of children between 8 and 11 years old. AAttanasio et al. (2006) find a reduction on child labor for the Colombian programme and Skoufias and Parker (2001) find a decrease in child labor in Mexico. For the Ecuadorian program Bono de Desarrollo Humano, AAraujo and Schady (2008) find a large positive impact on school enrolment.

There are a few papers that analyses the labor market impact of CCT programs. González-Cossío et al. (2008)' studies the Programa Apoyo Alimentario in rural southern Mexico and they find that the program does not have any impact on adult participation. However, they find a negative impact on agriculture participation and a positive effect on non agriculture participation. Skoufias and di Maro (2006) find that the Mexican PROGRESA period has no impact on adult labor force participation. Finally, Britto, Medeiros and Soares (2008) conclude for the Brazilian case that the programme has no negative impact on the labor market.

\section{Ingreso CiUdadano Program}

The Ingreso Ciudadano program was implemented between April 2005 and December 2007 as a monetary benefit per household, equivalent to USD 56 in 2005 USD. The cash benefit was received monthly and payment amounts were updated every four months according to the Consumer Price Index (Indice de Precios al Consumo, IPC). The payment was conditioned on school enrolment (and 
attendance) and regular health status control for the children of the households. The payment could be suspended because of not fulfilling the co-responsibilities without justification of the counterparts.

The Ingreso Ciudadano program defined its target population as the first quantile of people below the poverty line according to the INE, 2002. The targeting method consists of two criteria: i) an upper per capita income limit; to receive the cash benefit, the household must have had a monthly per capita income lower than USD 51 and ii) a Critical Lack Index (CLI); households with a CLI above a particular value established by the authorities were selected. This index is a proxy means tests and it was used due to difficulties in the verification of household incomes given the size of the informal sector in Uruguay.

The CLI was calculated in the following way:

$$
C L I_{i}=N\left(\sum_{k} X_{i k} \beta_{k}\right)
$$

where $i$ refers to household; $N$ is the accumulated distribution from the normal standard function; $X_{i k}$ is a vector from $K$ variables selected on the basis of an estimation of a probit model where the dependant variable is a dummy that takes the value of one if the household belongs to the first quantile of poor households (according to the poverty line established by the INE methodology 2002), and zero if the household is poor but does not belong to the first quantile; and $\beta_{k}$ are the coefficients associated to each variable. The probit model was estimated for Montevideo and the urban areas based on the 2003 and 2004 ECH. For the rural areas, information from the Survey of Expenditure and Income of 1999 was used. The information of the group of variables $X_{i k}$ for the calculation of the CLI of the applicants was obtained from the application forms. The thresholds (cut off point) were defined for five different regions (Table 1).

TABLE 1

THRESHOLDS BY REGION OF THE COUNTRY

\begin{tabular}{ll}
\hline Region & Limit \\
\hline Montevideo & 0.191 \\
North (urban areas) & 0.085 \\
North center (urban areas) & 0.055 \\
South center (urban areas) & 0.067 \\
South (urban areas) & 0.098 \\
\hline
\end{tabular}

Source: Amarante et al. (2005)

North of the country included Artigas, Salto and Rivera; north centre of the country included Paysandú, Rio Negro, Tacuarembó, Durazno, Treinta y Tres and Cerro Largo; south centre of the country included Soriano, Florida, Flores, 
Lavalleja and Rocha; and finally south of the country included Colonia, San José, Canelones and Maldonado. The information to obtain the threshold levels for rural areas was not found and it was not in any public document. Therefore, this paper estimates the program impact on urban areas which nonetheless account for $93 \%$ of the population according to the INE.

\section{DATA}

To undertake this study of the impact of the CCT program in Uruguay on school attendance, child labor and labor supply we use the annual Uruguayan National Household Survey $(\mathrm{ECH})$ conducted yearly by the National Statistical Office of Uruguay, INE. We use cross sectional data for 2006 and 2007.

The ECH is the main source of socio-economic information about Uruguayan households at the national level. In the 2006 and $2007 \mathrm{ECH}$, rural areas and urban areas with less than 5000 inhabitants were included. The surveys were carried out through out the year with the objective of generating a proper description of the socio-economic situation of the entire population of Uruguay.

In the $2006 \mathrm{ECH}$, several quarterly modules concentrating on different issues, like housing, child labor, national and international migration, technology and communication, were included. For this reason, and unlike the prior household's surveys, the sample size was increased. The $2006 \mathrm{ECH}$ has 256,866 observations (individuals) belonging to 85,316 households with $5.4 \%$ of the households receiving Ingreso Ciudadano. In the $2006 \mathrm{ECH}$ there is information about child labor. The 2007 ECH surveyed 143,185 individuals belonging to 49,136 households. In the 2007 survey, $5.7 \%$ of the households received Ingreso Ciudadano. The Appendix provides simple descriptive statistics for the data used in this study. Table 2 shows the distribution of the households who received Ingreso Ciudadano by region.

TABLE 2

BENEFICIARY HOUSEHOLDS BY REGION OF THE COUNTRY

\begin{tabular}{lccccc}
\hline & \multicolumn{2}{c}{2006} & & \multicolumn{2}{c}{2007} \\
\cline { 2 - 3 } \cline { 5 - 6 } Region & $\begin{array}{c}\text { Beneficiaries } \\
\text { households }\end{array}$ & $\%$ & & $\begin{array}{c}\text { Beneficiaries } \\
\text { household }\end{array}$ & $\%$ \\
\hline Montevideo & 16,266 & 27 & & 16,205 & 25 \\
North (urban areas) & 9,511 & 16 & & 10,164 & 15 \\
North center (urban areas) & 12,359 & 21 & & 12,610 & 19 \\
South center (urban areas) & 6,820 & 11 & & 6,890 & 11 \\
South (urban areas) & 11,996 & 20 & & 14,534 & 22 \\
Rural areas & 2,855 & 5 & & 5,128 & 8 \\
Total & 59,808 & 100 & & 65,531 & 100 \\
\hline
\end{tabular}

Source: Own elaboration based on the ECH 2006 and ECH 2007 
Despite the fact that from 2002 the extreme poverty indicator showed higher values in Montevideo than in the rest of the urban country (Amarante and Vigorito, 2006), we observe that more than a $70 \%$ of the beneficiaries households were from the rest of the urban areas (see Table 2). This targeting problem could be a consequence of setting a targeting criterion (in this case the upper per capita income limit) for the whole country without considering differences in the cost of living between the capital city and the rest of the country. According to the information of INE (for December 2007), the average income of households from Montevideo is $46 \%$ higher than the income from the rest of the urban country (USD 1,064 against USD 728).

In $2006,62 \%$ of the households that fulfilled the targeting criteria got the cash benefit (see Table 3). While the $38 \%$ of the households that fulfilled the targeting criteria did not receive the cash benefit. In 2007, the targeting performance improved, reaching the $72 \%$ of the eligible households. In both years, only the $1 \%$ of the households that did not fulfill the requirements received the cash benefit.

TABLE 3

TARGETING PERFORMANCE

(Urban Uruguay)

\begin{tabular}{lccccc}
\hline & \multicolumn{3}{c}{ Fulfilled the targeting criteria? } \\
\cline { 2 - 4 } \cline { 5 - 6 } & \multicolumn{2}{c}{2006} & & \multicolumn{2}{c}{2007} \\
\cline { 2 - 5 } \cline { 5 - 6 } & Yes & No & & Yes & No \\
\hline Received cash benefit & 62 & 1 & & 72 & 1 \\
Not receive cash benefit & 38 & 99 & & 28 & 99 \\
Total & 100 & 100 & & 100 & 100 \\
\hline
\end{tabular}

Source: Own elaboration based on the ECH 2006 and ECH 2007.

The targeting performance of the Ingreso Ciudadano program is similar to the results showed in conditional cash transfer policies implemented in the region (Rawlings, 2005 and CEPAL, 2006). However, is difficult to compare results because many of these programs were focused on population located in areas with difficult access due to geography accidents and different cultures and languages (Attanasio et al., 2005 and 2006). We do not expect to observe these difficulties in a small country like Uruguay especially given that we are considering only urban areas.

\section{Methodology}

In this section we discuss the methodology employed to evaluate the impact of the Ingreso Ciudadano program. The standard for assessing causality from program participation to outcome variables is to use a randomized experiment. In 
a randomized experiment individuals are chosen at random from the population. We refer to this group as the experimental or treatment group. Since these subjects have been selected at random, they must be, on average, identical in characteristics to the "non-picked" or "control" group. The experimental group is then "treated" with the program. Next we compare the experimental group to the control group after the treatment is applied to the experimental group and any differences in outcomes observed in the two can be attributed to the treatment since the two groups were identical before treatment. In this manner we avoid the selection bias problem, permitting us to assess causality from treatment to outcome.

With respect to Ingreso Ciudadano program, assignment to the treatment group was not random. The selection into the program depended on the value of an observed continuous variable (CLI) relative to a given threshold. This kind of treatment assignment has us consider use of a quasi-experimental design, regression discontinuity (RD), in order to assess the impact of the program. There are two types of RD designs: sharp design, in which the treatment assignment is a deterministic function of only one selection variable and so the probability of receiving the treatment jumps from zero to one at the threshold; and fuzzy design, in which the treatment assignment depends stochastically on the selection variable and it also depend on other unobserved variables, so the probability of receiving the treatment does not jump from zero to one at the threshold. The fuzzy design holds when there are others assignment rules, which are only observed by the treatment administrator. Figure 2 shows the probability of receive the treatment given the selection variable. The figure suggests the absence of discontinuity near the threshold (standardized at zero) ${ }^{3}$.

In addition, the RD design needs the following identifying assumption: the discontinuity in the treatment variable occurs at the cut-off point of the CLI. Following the procedure suggested by Nichols (2007), we estimate a local linear regression at each side of the cut-off point. Then we compute the difference only using the predictions at 0 (the threshold), and finally, we bootstrap the difference so as to make inference. The test shows that this assumption does not hold (Table 4). Consequently, the application of a RD design is not plausible for the evaluation of the Ingreso Ciudadano program.

As a substitute, we carry out a matching technique — we find a "control group" that matches the "experimental group"-the set of households that participate in the program. That is, we simulate a randomized experiment by finding a control group among those households who are not participant households (but who fulfilled the requirements to be in the program). We work backwards in comparison to a randomized experiment. We are presented with a treated group. This method involves finding a control group that matches the treated group. We use this "matched control" group to derive comparisons with the "treated" group. In this way we can discern causality from program participation to outcomes variables and thereby make inferences about the impact of the Ingreso Ciudadano program.

3 Manacorda et al. (2009) using non public data from MIDES find a discontinuity near the threshold. 
FIGURE 2

PROBABILITY OF RECEIVING THE TREATMENT GIVEN THE STANDARDIZED SELECTION INDEX

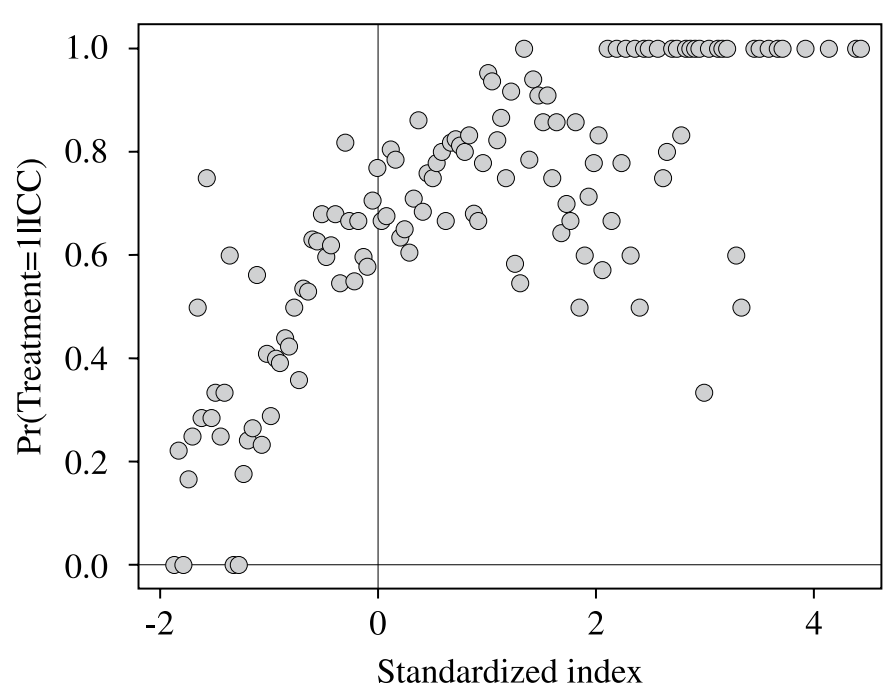

Source: Computed by the authors using the $2007 \mathrm{ECH}$.

Note: Using the ECH 2006, we observe the same description of the data.

TABLE 4

REGRESSION DISCONTINUITY IDENTIFYING ASSUMPTION TEST

\begin{tabular}{lccccc}
\hline Year & $\begin{array}{c}\text { Observed } \\
\text { coeficient }\end{array}$ & $\begin{array}{c}\text { Bootstrap } \\
\text { error }\end{array}$ & $\mathrm{P}>\mathrm{z}$ & $\begin{array}{c}\text { Normal-based } \\
{[95 \% \text { conf. interval] }}\end{array}$ \\
\hline 2006 & 0.09 & 0.07 & 0.18 & -0.04 & 0.22 \\
2007 & -0.08 & 0.09 & 0.39 & -0.25 & 0.10 \\
\hline
\end{tabular}

Source: Own estimations based on the 2006 and 2007 ECH.

Note: Standard error in parenthesis. Bootstrap standard error based on 1000 replications, * statistically different from zero at the $1 \%$ level.

In this paper we use propensity score matching (PSM) to obtain an artificially generated control group that is similar to the treatment group in every aspect except that a person in the control group does not receive the cash transfer (Heckman et al.,1997). The identification condition is that for some explicative variables $X$ the group of control has to be similar to the group of treatment: $\mathrm{E}\left[Y_{0} \mid X, I=1\right]=\mathrm{E}\left[Y_{0} \mid X, I=0\right]=\mathrm{E}\left[Y_{0} \mid X\right]$ 
Where $Y$ is the outcome variable (school attendance, child labor, labor supply), $X$ represents control variables (or characteristics), $I$ take value of one if the households receives transfers and zero if they does not receive it.

Rosenbaun and Rubin (1983) show that it is not necessary to perform the matching with respect to the vector of household characteristics $X$. It is enough to match the propensity score, that is, the predicted probability of treatment receipt (in our case program participation) given a vector of covariates. Therefore, so as to obtain the artificially created control group one needs to first obtain the propensity score for each observation that "orders" observations along a set of observable variables. For each treated observation we find the non-treated observation applying a Kernel matching giving the highest weight to individuals with propensity score closes to the score of the treated group (belonging to the region of common support).

That is, we obtain predicted probabilities $p(X)$ from a probit that predicts program participation and then use these predicted probabilities to Kernel match non-participant households to participant households. PSM method normally assumes that there exists a region of "common support", where propensity score of treated and non-treated overlap and therefore a robust comparison can be done (see Figure 3).

FIGURE 3

REGION OF COMMON SUPPORT

2006

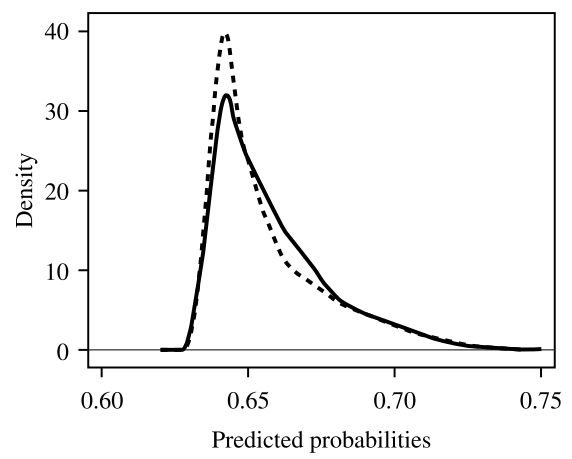

2007

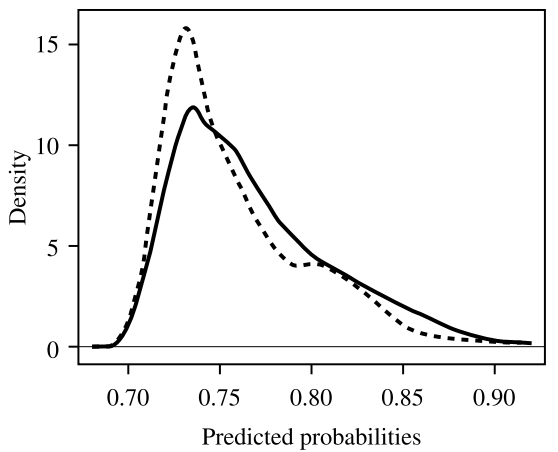

Treated - - - - . Non-treated

Source: Authors' estimations based on the 2006 and 2007 ECH.

In a second step, we match households with replacement based in $p(X)$ where a household receives the treatment and the other does not. In this way we calculate to estimate the counterfactual of no treatment. We do the matching of households in $p(X)$ and not in $X$ directly because the estimating matching is difficult to implement when the dimension of $X$ is high. 
So the PSM estimator has the following structure:

$$
E\left[Y_{1}-Y_{0} \mid p(\hat{X})\right]=\frac{1}{N_{1}} \sum_{i \in T_{1}}\left[Y_{1 i}-\hat{E}\left[Y_{0 i} \mid I_{i}=1, p\left(X_{i}\right)\right]\right]
$$

where

$$
\hat{E}\left[\hat{E}\left[Y_{0 i} \mid I_{i}=1, p\left(X_{i}\right)\right]\right]=\sum_{j \in T_{1}} W(i, j) Y_{0 j}
$$

and $W(i, j)$ is a Kernel function

The most important limitation of the PSM estimator is that the identification condition does not allow selection on unobservable. This methodology, enable us to eliminate the selection bias based on "observables", and thus reducing the "aggregate bias", only if the selection bias based on "unobservable factor" goes in the same direction than the former. Otherwise, the "aggregate bias" will probably rise. Despite the latter case does not usually appear in the empirical evidence, it is better to know at which level the assignment depend on "unobservable". When the treatment assignment rule is of public knowledge, we might expect that some households adjust their behaviour in order to get treated, and so the treatment could depend on unobservable factors. This behaviour is what Mc Crary (2008)' defined as "manipulation of the running variable" (selection variable). He proposed a discontinuity test to detect manipulation. We undertook the test in each region, selecting the household with a per capita income lower than the upper per capita income limit. For 2006, the test suggests that there was no manipulation (see Appendix, table A.1). The same results hold in the 2007 data. This is an expected result since it was difficult that the households control the selection variable.

The PSM is an appropriate methodology if we can control with a rich group of variables. The extensive samples in the 2006 and 2007 Uruguayan household surveys allow us to have a large number of control variables and observations, which reduces the cost between changes and accuracy in the second stage of implementation of the PSM estimator.

In this way, the average treatment effect measures the impact of treatment (taking part in the Ingreso Ciudadano program), in the group of homes that receive the benefit. The algorithm used to make the matching between the potential controls and the treated is PSMATCH2, version 3.0, developed by Leuven and Sianesi (2003).

Of particular concern in any study using non-experimental data is whether indeed the control group serves as a good comparison for the treated group. Can we "after the fact" demonstrate that the control group resembles the treated group in the pre-treatment time period? How accurate is our matching? Do the matched controls really serve as counterfactuals to the treated group? To gain some insights into the comparability of the treated with the matched controls we will report on a series of descriptive statistics for three groups: i) the treated group - households receiving Ingreso Ciudadano - ii) the untreated group - households non receiving Ingreso Ciudadano - ; iii) the matched controls - a subset of the untreated - those 
with propensity scores closed to the scores of the treated group, belonging to the region of common support.

\section{The Ingreso Ciudadano Program Impact}

In this section, we quantify the impact of the program on school attendance, child labour and labour supply. We perform the evaluation considering two geographical areas: Montevideo and the rest of the urban country.

\subsection{School Attendance}

The CCTs programs use the cash benefit in order to enhance the human capital accumulation, and so positive results on school attendance are expected. For the assessment of the impact on school attendance, we generate a binary variable that takes the value of one if the child attends school or takes the value of zero if the child does not in 2006. In addition, we consider two cohorts defined by age, $[8,11]$ and $[12,14]$, because of the drop-out rate, which increase sharply since the age of 12 (the beginning of the high school). The attendance rate for children between 6 and 11 is nearly $100 \%$ '(Katzman and Rodríguez, 2006), owing to the fact that education is compulsory at this level. In the Appendix (Table B.1), we include the descriptive statistics of the sample selected for the evaluation of this variable.

In the case of teenagers between 12 and 17 years old, the attendance rate decrease to $85.1 \%$ for the whole country. If we only consider urban areas and Montevideo the drop-out rate is $12.9 \%$. In urban areas, the attendance rate of males is lower than females' attendance rate. When Katzman and Rodríguez (2006) analyze the attendance rate statistics for the poor population, they found that it decreases slightly, 75.7 and 80.6, for males and females respectively.

The results for the children between 8 and 11 years old, show that the Ingreso Ciudadano program had no significant effects on school attendance (see Table 5). We have to emphasize that the attendance rate for children between 8 and 11 are already high as we observe in the results. Therefore, it was not surprising to find no effect.

If we expect the program to enhance school attendance it is more likely to observe an impact in the youngest in high school. Table 6 shows no significant impact on the attendance rate for individuals between 12 and 14 years old.

We have to ask ourselves about the reliability of the matching. Do the matched controls really serve as counterfactuals to the treated group? In Table 7 we compare i) the treated group - Ingreso Ciudadano receiving households, ii) the untreated group - non-Ingreso Ciudadano receiving households and iii) the matched controls - a subset of the untreated- those with propensity score closest to the scores of the treated group, belonging to the region of common support. Results indicate that the matched male group is in fact indistinguishable from the treated group in all of the listed observable dimensions. None of the differences in means and proportions for the matched and treated group are statistically different from zero. The two groups seem identical. We only included the critical lack index and 
TABLE 5

AVERAGE TREATMENT EFFECT

(School attendance $[8,11]$ cohort, 2006)

\begin{tabular}{|c|c|c|c|c|c|c|}
\hline Region & Sex & $\begin{array}{l}\text { Treated } \\
\text { (1) }\end{array}$ & $\begin{array}{c}\text { Not } \\
\text { treated } \\
(2)\end{array}$ & $\begin{array}{c}\text { Test } \\
\mu_{(1)}-\mu_{(2)}=0\end{array}$ & $\begin{array}{l}\text { Matched } \\
\text { controls } \\
\text { (3) }\end{array}$ & $\begin{array}{c}\text { Test } \\
\mu_{(1)}-\mu_{(3)}=0\end{array}$ \\
\hline \multirow[t]{2}{*}{ Montevideo } & Male & $\begin{array}{c}0.99 \\
\mathrm{~N}=350\end{array}$ & $\begin{array}{c}0.99 \\
\mathrm{~N}=184\end{array}$ & $\begin{array}{c}0.00 \\
(0.01)\end{array}$ & $\begin{array}{c}0.99 \\
N=184\end{array}$ & $\begin{array}{c}0.00 \\
(0.01)\end{array}$ \\
\hline & Female & $\begin{array}{c}0.99 \\
\mathrm{~N}=336 \\
\end{array}$ & $\begin{array}{c}0.99 \\
\mathrm{~N}=223 \\
\end{array}$ & $\begin{array}{c}0.00 \\
(0.01) \\
\end{array}$ & $\begin{array}{c}0.99 \\
\mathrm{~N}=223 \\
\end{array}$ & $\begin{array}{c}0.00 \\
(0.01) \\
\end{array}$ \\
\hline \multirow[t]{2}{*}{$\begin{array}{l}\text { Rest of the } \\
\text { urban country }\end{array}$} & Male & $\begin{array}{c}0.99 \\
\mathrm{~N}=678\end{array}$ & $\begin{array}{c}0.99 \\
\mathrm{~N}=333\end{array}$ & $\begin{array}{c}0.00 \\
(0.01)\end{array}$ & $\begin{array}{c}0.99 \\
\mathrm{~N}=333\end{array}$ & $\begin{array}{c}0.00 \\
(0.01)\end{array}$ \\
\hline & Female & $\begin{array}{c}1.00 \\
\mathrm{~N}=655\end{array}$ & $\begin{array}{c}1.00 \\
\mathrm{~N}=285\end{array}$ & $\begin{array}{c}0.00 \\
(0.00)\end{array}$ & $\begin{array}{c}1.00 \\
\mathrm{~N}=285\end{array}$ & $\begin{array}{c}0.00 \\
(0.00)\end{array}$ \\
\hline
\end{tabular}

Source: Own estimations based on the ECH 2006.

Notes: Standard error in parenthesis. Bootstrap standard error based on 1000 replications for the After Matching test, *** statistically different from zero at $5 \%$ and $1 \%$ respectively.

TABLE 6

AVERAGE TREATMENT EFFECT

(School attendance [12,14] cohort, 2006)

\begin{tabular}{|c|c|c|c|c|c|c|}
\hline Region & Sex & $\begin{array}{l}\text { Treated } \\
\text { (1) }\end{array}$ & $\begin{array}{l}\text { Not } \\
\text { treated } \\
(2)\end{array}$ & $\begin{array}{c}\text { Test } \\
\mu_{(1)}-\mu_{(2)}=0\end{array}$ & $\begin{array}{l}\text { Matched } \\
\text { controls } \\
\text { (3) }\end{array}$ & $\begin{array}{c}\text { Test } \\
\mu_{(1)}-\mu_{(3)}=0\end{array}$ \\
\hline \multirow[t]{2}{*}{ Montevideo } & Male & $\begin{array}{c}0.86 \\
\mathrm{~N}=231\end{array}$ & $\begin{array}{c}0.83 \\
\mathrm{~N}=151\end{array}$ & $\begin{array}{c}0.03 \\
(0.04)\end{array}$ & $\begin{array}{c}0.86 \\
\mathrm{~N}=151\end{array}$ & $\begin{array}{c}0.00 \\
(0.05)\end{array}$ \\
\hline & Female & $\begin{array}{c}0.92 \\
\mathrm{~N}=235 \\
\end{array}$ & $\begin{array}{c}0.90 \\
\mathrm{~N}=121 \\
\end{array}$ & $\begin{array}{c}0.02 \\
(0.03) \\
\end{array}$ & $\begin{array}{c}0.94 \\
\mathrm{~N}=121 \\
\end{array}$ & $\begin{array}{c}-0.02 \\
(0.04) \\
\end{array}$ \\
\hline \multirow[t]{2}{*}{$\begin{array}{l}\text { Rest of the } \\
\text { urban country }\end{array}$} & Male & $\begin{array}{c}0.89 \\
\mathrm{~N}=451\end{array}$ & $\begin{array}{c}0.84 \\
\mathrm{~N}=206\end{array}$ & $\begin{array}{l}0.05 * \\
(0.03)\end{array}$ & $\begin{array}{c}0.82 \\
\mathrm{~N}=206\end{array}$ & $\begin{array}{c}0.07 \\
(0.04)\end{array}$ \\
\hline & Female & $\begin{array}{c}0.92 \\
\mathrm{~N}=428 \\
\end{array}$ & $\begin{array}{c}0.91 \\
\mathrm{~N}=209 \\
\end{array}$ & $\begin{array}{c}0.01 \\
(0.02) \\
\end{array}$ & $\begin{array}{c}0.90 \\
\mathrm{~N}=209 \\
\end{array}$ & $\begin{array}{c}0.02 \\
(0.03) \\
\end{array}$ \\
\hline
\end{tabular}

Source: Own estimations based on the ECH 2006.

Notes: Standard error in parenthesis. Bootstrap standard error based on 1000 replications for the After Matching test, *** statistically different from zero at $5 \%$ and $1 \%$ respectively.

social security transfers in the matching test because these variables are defined as function of the socioeconomic and housing characteristics of the households.

As discussed in the introduction when the primary school attendance is close to universal (as in Uruguay) the literature does not find impacts on school attendance. 


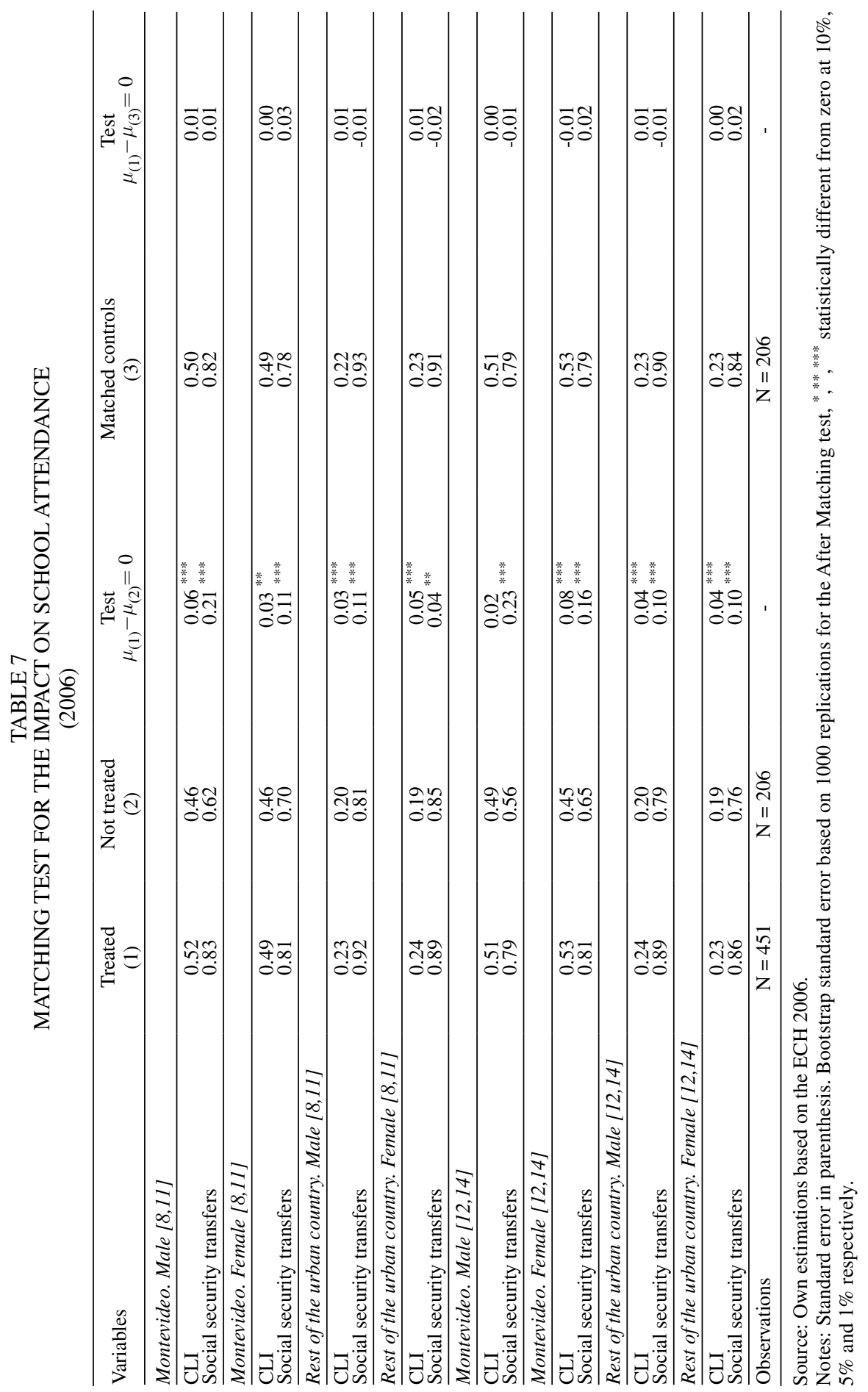




\subsection{Child Labor}

Although the reduction of child labor was not an explicit objective of the Ingreso Ciudadano program we evaluate the impact because the program could affect it. Children's time can be divided into schooling, child labour and leisure. CCT programs are intended to change the time allocation of the child between work and education, not leisure. The desired result is that increases in attendance rates reduce the proportion of working children. Given that we did not find a positive effect on the attendance rate, we also might expect no positive effects on child labour.

To assess the impact of the plan on child labour, we use the Child Labor module of the ECH 2006. In this module, there are a number of questions that enable us to identify child between 5 and 17 who are involved in economic activities. In this research, we define child labour as children between 6 and 15 years old ${ }^{4}$ who carry out paid or no paid activities outside the household and also who spend more than 3 hours working for the household. We refer to those activities that can affect the normal development of the child like bricklaying, street sale, farm work, housekeeping, etc. We chose this age interval in order to consider the entrance age of school (6 years old) and to take into account the minimum age to work recognized by the Childhood and Adolescence code (15 years old). For Montevideo the proportion of child labour is $4.5 \%$ and for the rest of the urban country it is $5.4 \%$, and it is positively correlated with the age.

The outcome variable is a binary variable that takes the value of one when the child/adolescent has positive work hours outside the household and more than 3 hours working for the household, and takes the value of zero otherwise. Table 8 shows only a reduction of the proportion of working female children living in Montevideo.

TABLE 8

AVERAGE TREATMENT EFFECT

(Child labour [6,14], 2006, second quarter)

\begin{tabular}{|c|c|c|c|c|c|c|}
\hline Region & Sex & $\begin{array}{c}\text { Treated } \\
\text { (1) }\end{array}$ & $\begin{array}{c}\text { Not } \\
\text { treated } \\
(2)\end{array}$ & $\begin{array}{c}\text { Test } \\
\mu_{(1)}-\mu_{(2)}=0\end{array}$ & $\begin{array}{c}\text { Matched } \\
\text { controls } \\
\text { (3) }\end{array}$ & $\begin{array}{c}\text { Test } \\
\mu_{(1)}-\mu_{(3)}=0\end{array}$ \\
\hline \multirow[t]{2}{*}{ Montevideo } & Male & $\begin{array}{c}0.21 \\
\mathrm{~N}=183\end{array}$ & $\begin{array}{c}0.18 \\
\mathrm{~N}=133\end{array}$ & $\begin{array}{c}0.03 \\
(0.05)\end{array}$ & $\begin{array}{c}0.22 \\
\mathrm{~N}=133\end{array}$ & $\begin{array}{l}-0.03 \\
(0.06)\end{array}$ \\
\hline & Female & $\begin{array}{c}0.14 \\
\mathrm{~N}=195\end{array}$ & $\begin{array}{c}0.24 \\
\mathrm{~N}=143\end{array}$ & $\begin{array}{l}-0.10^{* *} \\
(0.04)\end{array}$ & $\begin{array}{c}0.28 \\
\mathrm{~N}=143\end{array}$ & $\begin{array}{l}-0.14^{* *} \\
(0.05)\end{array}$ \\
\hline \multirow[t]{2}{*}{$\begin{array}{l}\text { Rest of the urban } \\
\text { country }\end{array}$} & Male & $\begin{array}{c}0.13 \\
\mathrm{~N}=434\end{array}$ & $\begin{array}{c}0.12 \\
\mathrm{~N}=173\end{array}$ & $\begin{array}{c}0.01 \\
(0.03)\end{array}$ & $\begin{array}{c}0.13 \\
\mathrm{~N}=173\end{array}$ & $\begin{array}{c}0.00 \\
(0.04)\end{array}$ \\
\hline & Female & $\begin{array}{c}0.15 \\
\mathrm{~N}=398\end{array}$ & $\begin{array}{c}0.16 \\
\mathrm{~N}=167\end{array}$ & $\begin{array}{l}-0.01 \\
(0.03)\end{array}$ & $\begin{array}{c}0.15 \\
\mathrm{~N}=167\end{array}$ & $\begin{array}{c}0.00 \\
(0.04)\end{array}$ \\
\hline
\end{tabular}

Source: Own estimations based on the ECH 2006.

Notes: Standard error in parenthesis. Bootstrap standard error based on 1000 replications for the After Matching test, *** statistically different from zero at $5 \%$ and $1 \%$ respectively.

4 See the Table B.3 in the Appendix for descriptive statistics of the sample selected. 
The Table 9 presents the matching test for the impact of the program on child labor. As in the school attendance case the matched control is similar to the treated group.

TABLE 9

MATCHING TEST FOR THE IMPACT ON CHILD LABOR

(6 to 14 years old, 2006)

\begin{tabular}{|c|c|c|c|c|c|c|c|}
\hline Region & Sex & Variable & $\begin{array}{l}\text { Treated } \\
\text { (1) }\end{array}$ & $\begin{array}{l}\text { Not } \\
\text { treated } \\
(2)\end{array}$ & $\begin{array}{c}\text { Test } \\
\mu_{(1)}-\mu_{(2)}=0\end{array}$ & $\begin{array}{l}\text { Matched } \\
\text { controls } \\
\text { (3) }\end{array}$ & $\begin{array}{c}\text { Test } \\
\mu_{(1)}-\mu_{(3)}=0\end{array}$ \\
\hline \multirow[t]{4}{*}{ Montevideo } & Male & CLI & 0.53 & 0.48 & $0.05 *$ & 0.51 & 0.00 \\
\hline & & $\begin{array}{l}\text { Social security } \\
\text { transfers }\end{array}$ & 0.85 & 0.66 & $0.19 * * *$ & 0.81 & 0.03 \\
\hline & Female & CLI & 0.49 & 0.48 & 0.01 & 0.49 & -0.01 \\
\hline & & $\begin{array}{l}\text { Social security } \\
\text { transfers }\end{array}$ & 0.84 & 0.69 & $0.15 * * *$ & 0.85 & 0.00 \\
\hline \multirow{4}{*}{$\begin{array}{l}\text { Rest of the } \\
\text { urban country }\end{array}$} & Male & CLI & 0.23 & 0.19 & $0.04 * * *$ & 0.22 & 0.00 \\
\hline & & $\begin{array}{l}\text { Social security } \\
\text { transfers }\end{array}$ & 0.90 & 0.80 & $0.10 * * *$ & 0.92 & -0.02 \\
\hline & Female & CLI & 0.24 & 0.19 & $0.05 * * *$ & 0.23 & 0.01 \\
\hline & & $\begin{array}{l}\text { Social security } \\
\text { transfers }\end{array}$ & 0.90 & 0.82 & $0.08 * * *$ & 0.90 & 0.00 \\
\hline
\end{tabular}

Source: Own estimations based on the ECH 2006.

Notes: Standard error in parenthesis. Bootstrap standard error based on 1000 replications for the After Matching test, $* * *$ statistically different from zero at $5 \%$ and $1 \%$ respectively.

As presented in the introduction the literature, we find zero or negative impact on child labor. In the Uruguayan case we find a negative effect only for girls in the capital, Montevideo.

\subsection{Labour Market}

One of the main concerns of CCT programs is their potential to provide disincentive to work. For example, the cash transfer shifts the budget constraint of the household, and this enables it to substitute leisure for labor and continue consuming the same basket of goods 5 . Therefore, the benefit potentially gives an incentive to reduce recipients work hours, or to even opt out of the labour market. In addition, people who are interested in being treated could adjust their behaviour in order to fulfil the requirement to be in the program. For example, employees could arrange with employers to work "off the books" which enables

\footnotetext{
5 That is the case when the substitute effect is stronger than the income effect.
} 
the employee to under report their income and increase the likelihood of being selected into the program. So, CCT could also lead to an increase in the number of people working in the informal labour market (defined as the sector of the economy that does not comply with labour market legislation and compliance with social security taxes).

We construct three variables to quantify the effect of the program on the labour market: 1) Worked Hours, which is the number of worked hours per week; 2) Rate of Participation, which is a dummy variable that takes the value one if the person is economically active (employed and unemployed workers) and takes the value zero otherwise; 3) Informal Worker, which is also a dummy variable that takes the value one if the worker has not complied with social security laws and takes zero value otherwise.

To evaluate the impact on worked hours and on informality, we select the observation that fulfil the requirements to be in the program and that also have positive worked hours. In the case of the assessment of the rate of participation, we select the observations only with the first condition. Additionally, for the evaluation of the three outcome variables we only take into account people between 22 and 55 years old, evaluating them separately by gender and region (Montevideo and rest of the urban country). We present the descriptive statistics of the sample selected in the Appendix (Tables B.3 and B.4).

Using the $2006 \mathrm{ECH}$, we find a negative and significant effect of the program on worked hours (mainly for women) only for the rest of the urban country (see Table 10). For the rest of the urban country, men and women in an Ingreso Ciudadano receiving households work on average 2.5 and 6.4 hours less per week.

TABLE 10

AVERAGE TREATMENT EFFECT ON TOTAL HOURS OF WORK

(Individuals between 22 and 55 years old, 2006)

\begin{tabular}{|c|c|c|c|c|c|c|}
\hline Region & Sex & $\begin{array}{c}\text { Treated } \\
\text { (1) }\end{array}$ & $\begin{array}{c}\text { Not } \\
\text { treated } \\
(2)\end{array}$ & $\begin{array}{c}\text { Test } \\
\mu_{(1)}-\mu_{(2)}=0\end{array}$ & $\begin{array}{l}\text { Matched } \\
\text { controls } \\
\text { (3) }\end{array}$ & $\begin{array}{c}\text { Test } \\
\mu_{(1)}-\mu_{(3)}=0\end{array}$ \\
\hline \multirow[t]{2}{*}{ Montevideo } & Male & $\begin{array}{c}37.9 \\
N=435\end{array}$ & $\begin{array}{c}40.5 \\
N=325\end{array}$ & $\begin{array}{l}-2.6^{*} \\
(1.4)\end{array}$ & $\begin{array}{c}40.2 \\
N=325\end{array}$ & $\begin{array}{l}-2.4 \\
(1.5)\end{array}$ \\
\hline & Female & $\begin{array}{c}26.1 \\
N=273\end{array}$ & $\begin{array}{c}26.9 \\
N=243\end{array}$ & $\begin{array}{l}-0.9 \\
(1.8)\end{array}$ & $\begin{array}{c}26.3 \\
N=243\end{array}$ & $\begin{array}{c}-0.2 \\
(1.9)\end{array}$ \\
\hline \multirow[t]{2}{*}{$\begin{array}{l}\text { Rest of the } \\
\text { urban country }\end{array}$} & Male & $\begin{array}{c}39.9 \\
N=827\end{array}$ & $\begin{array}{c}42.0 \\
N=543\end{array}$ & $\begin{array}{l}-2.1^{*} \\
(1.0)\end{array}$ & $\begin{array}{c}42.4 \\
N=543\end{array}$ & $\begin{array}{l}-2.5^{*} \\
(1.0)\end{array}$ \\
\hline & Female & $\begin{array}{c}23.2 \\
\mathrm{~N}=483\end{array}$ & $\begin{array}{c}28.9 \\
N=312\end{array}$ & $\begin{array}{l}-5.7^{* *} \\
(1.4)\end{array}$ & $\begin{array}{c}29.5 \\
N=312\end{array}$ & $\begin{array}{l}-6.4^{* *} \\
(1.7)\end{array}$ \\
\hline
\end{tabular}

Source: Own estimations based on the ECH 2006.

Notes: Standard error in parenthesis. Bootstrap standard error based on 1000 replications for the After Matching test, *** statistically different from zero at $5 \%$ and $1 \%$ respectively. 
In order to clearly appreciate the reduction in worked hours, we calculate it as a percentage of average worked hours for the corresponding region. We observe a decrease in the men's labour supply of $5.1 \%$ and a decrease in the women's labour supply of $17 \%$ in the test of the urban country.

Table 11 shows that the matched controls serve as counterfactuals to the treated group. Our matching seems to have selected an appropriate control group.

\section{TABLE 11}

MATCHING TEST FOR THE IMPACT ON TOTAL HOURS OF WORK

(Rest of the urban country, 2006)

\begin{tabular}{|c|c|c|c|c|c|c|}
\hline Sex & Variables & $\begin{array}{c}\text { Treated } \\
\text { (1) }\end{array}$ & $\begin{array}{c}\text { Not } \\
\text { treated } \\
(2)\end{array}$ & $\begin{array}{c}\text { Test } \\
\mu_{(1)}-\mu_{(2)}=0\end{array}$ & $\begin{array}{c}\text { Matched } \\
\text { controls } \\
\text { (3) }\end{array}$ & 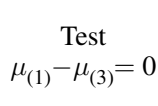 \\
\hline Male & $\begin{array}{c}\text { CLI } \\
\text { Social security } \\
\text { transfers }\end{array}$ & $\begin{array}{l}0.21 \\
0.85\end{array}$ & $\begin{array}{l}0.18 \\
0.74\end{array}$ & $\begin{array}{l}0.03^{* * * *} \\
0.11^{* * *}\end{array}$ & $\begin{array}{l}0.21 \\
0.86\end{array}$ & $\begin{array}{r}0.00 \\
-0.01\end{array}$ \\
\hline Female & $\begin{array}{c}\text { CLI } \\
\text { Social security } \\
\text { transfers }\end{array}$ & $\begin{array}{l}0.20 \\
0.89\end{array}$ & $\begin{array}{l}0.17 \\
0.78\end{array}$ & $\begin{array}{l}0.03^{* * * *} \\
0.11^{* * *}\end{array}$ & $\begin{array}{l}0.20 \\
0.91\end{array}$ & $\begin{array}{r}0.00 \\
-0.02\end{array}$ \\
\hline
\end{tabular}

Source: Own estimations based on the ECH 2006.

Notes: Standard error in parenthesis. Bootstrap standard error based on 1000 replications for the After Matching test, $* * *$ statistically different from zero at $5 \%$ and $1 \%$ respectively.

We do not find any impact of the Ingreso Ciudadano program on participation rate and informality ${ }^{6}$. As mentioned in the introduction the literature generally does not find significant impacts of the programs on labor supply. Our work suggests that the disincentives to work are relevant in the Uruguayan case.

\subsection{Robustness check}

As a robustness check and given the fact than in Section 3 we show that the focalization of the program improved in the year 2007, we estimate the impact on school attendance and labor supply using the ECH $2007^{7}$. Similar to the year 2006 we find no effect on school attendance in 2007 . The negative effect on labor supply in the rest of the urban country continues in 2007 (see Table 12).

When we use the $2007 \mathrm{ECH}$ two facts arise. On one hand, in 2007 the program is better targeted than in 2006 as we discuss above. For that reason, we observe fewer observations in the control group in relation with the treatment

\footnotetext{
6 We do not report the coefficients here, but the estimates are available from the authors upon request.

7 We can not estimate the impact in child labor because the ECH 2007 does not contain information about child labor.
} 
TABLE 12

AVERAGE TREATMENT EFFECT. TOTAL HOURS OF WORK

(Individuals between 22 and 55 years old, 2007)

\begin{tabular}{lcccccc}
\hline Region & Sex & $\begin{array}{c}\text { Treated } \\
(1)\end{array}$ & $\begin{array}{c}\text { Not } \\
\text { treated } \\
(2)\end{array}$ & $\begin{array}{c}\text { Test } \\
\mu_{(1)}-\mu_{(2)}=0\end{array}$ & $\begin{array}{c}\text { Matched } \\
\text { controls } \\
(3)\end{array}$ & $\begin{array}{c}\text { Test } \\
\mu_{(1)}-\mu_{(3)}=0\end{array}$ \\
\hline $\begin{array}{l}\text { Rest of the } \\
\text { urban country }\end{array}$ & Male & 36.1 & 40.4 & $-4.3^{* *}$ & 41.0 & $-5.1^{* * *}$ \\
& & $\mathrm{~N}=498$ & $\mathrm{~N}=197$ & $(1.5)$ & $\mathrm{N}=197$ & $(1.7)$ \\
& Female & 22.5 & 24.9 & -2.4 & 25.4 & -2.9 \\
& & $\mathrm{~N}=335$ & $\mathrm{~N}=147$ & $(1.9)$ & $\mathrm{N}=147$ & $(2.2)$ \\
\hline
\end{tabular}

Source: Own estimations based on the ECH 2007.

Notes: Standard error in parenthesis. Bootstrap standard error based on 1000 replications for the After Matching test, *** statistically different from zero at $5 \%$ and $1 \%$ respectively.

group. On the other hand, the sample size of the 2006 survey is much larger than the 2007 survey, so we have a smaller treatment and control group in 2007. Despite these two facts, we find negative effects on labour supply for the rest of the urban country. Therefore, we can conclude that our results are robust.

\section{CONCLUSIONS}

This paper seeks to determine whether the participation in the Uruguayan conditional cash transfer Ingreso Ciudadano impacts on the school attendance, child labor and labor supply of household members. Such assessment is desirable in terms of the evaluation of the program. While there has been a considerable work about the impact of CCT programs in Latin America there is a limited amount of work that analyze the impact of the Uruguayan CCT program.

We show that the threshold to enter to the program has not been respected in the practice. This invalidates the use of regression discontinuity analysis. In this paper we use a propensity score matching procedure to assess the casual impact of the program. We find that the Ingreso Ciudadano program has no impact on school attendance, it reduces female child labor in Montevideo and it reduces total hours of work in the rest of the urban country. Our work suggests that the disincentives to work are relevant in the Uruguayan case. 


\section{REFERENCIAS}

Amarante, V. and A.Vigorito (2006), "Evolución de la Pobreza en el Uruguay", Instituto Nacional de Estadística, (INE).

Amarante, V., R. Arim and A. Vigorito (2005), "Metodología para la Selección de Participantes en el Plan de Emergencia Social", Convenio MIDES-UDELAR.

Araujo, M. and N. Schady (2008), "Cash Transfers, Conditions, and School Enrollment in Ecuador" Economía, 8(2): 43-70.

Attanasio, O., E. Battistin, E. Fitzsimons,A. Gomez, D. Lopez, C. Meghir and A. Mesnard (2006), "Child Education and Work Choices in the Presence of a Conditional Cash Transfer Programme in Rural Colombia". The Institute for Fiscal Studies, WP06/01.

Attanasio, O., E. Battistin, E. Fitzsimons, A. Mesnard and M. Vera-Hernández (2005), "How Effective are Conditional Cash Transfers? Evidence from Colombia" The Institute for Fiscal Studies. Briefing Note No. 54.

Barham, B. and S. Gitter (2008), "Women Power, Conditional Cash Transfer and Scholing in Nicaragua", The Word Economic Review, 22(2):271-290.

Behrman, J., P. Sengupta and P. Todd (2005), "Progressing through Progresa: an Impact Assessment of a School Subsidy in Mexico". Economic Development and Cultural Change, 54(1):237-275.

Behrman, J., P. Sengupta and P. Todd (2001), "Progressing Through PROGRESA: an Impact Assessment of a School Subsidy Experiment”, mimeo, Penn Institute for Economic Research.

Behrman, J., P. Sengupta and P. Todd (2000), “The Impact of PROGRESA on Achievement Test Scores in the First Year", mimeo, International Food Policy Research Institute.

Beltrami, M., (2002), "Evolución de la Pobreza por el Método del Ingreso. Uruguay 19862001”. Instituto Nacional de Estadística.

Britto, T., M. Medeiros and F. Soares (2008), "Targeted Cash Transfer Programmes in Brazil: BPC and the Bolsa Familia". International Policy Centre for Inclusive Growth, Working Paper 46.

Bourguignon, F., F.H.G Ferreira and P. Leite (2003), "Conditional Cash Transfers, Schooling and Child Labor: Micro-Simulating Brazil's Bolsa Escola", World Bank Economic Review, 17(2): 229-54.

Bucheli, M. and M. Furtado (2004), "Uruguay 1998-2002: ¿Quiénes Ganaron and Quiénes Perdieron en la Crisis?", mimeo, trabajo de consultoría realizado para CEPAL, Oficina de Montevideo, 2004.

Cardoso, E. and A. Portela (2004), "The Impact of Cash Transfer on Child Labor and School, Attendance in Brazil", Working Paper No. 04-W07, Department of Economics, Vanderbilt University.

CEPAL (2006), "La Protección Social de Cara al Futuro. Acceso, Financiamiento and Solidaridad". CEPAL.

De Armas , G. (2004), "Pobreza and desigualdad en Uruguay. Claves para el Diseño de un Programa de Superación de la Pobreza Extrema", FESUR.

González-Cossío, T., M. Unar and E. Skoufias (2008), "The Impacts of Cash and In-Kind Transfers on Consumption and Labor Supply: Experimental Evidence from Rural Mexico", World Bank Policy Research Working Paper No. 4778.

Heckman, J.J., H. Ichimura and P. Todd (1997), "Matching as an Econometric Evaluation Estimator: Evidence from Evaluating a Job Training Programme". Review of Economic Studies,64(4):605-654. 
Kaztman, R. and Rodríguez, F. (2006). "Situación de la Educación en Uruguay: Análisis de los Datos de la Encuesta Nacional de Hogares Ampliada de 2006". Instituto Nacional de Estadística.

Leuven, E. and B. Sianesi. (2003), "PSMATCH2: Stata Module to Perform Full Mahalanobis and Propensity Score Matching, Common Support Graphing, and Covariate Imbalance Testing", URL: http://ideas.repec.! org/c/boc/bocode/s $432001 . h t m l$.

Manacorda, M., E. Miguel and A. Vigorito (2009), "Government Transfers and Political Support", NBER Working Paper No. 14702.

Mc Crary, J. (2008), "Manipulation of the Running Variable in the Regression Discontinuity Design: A Density Test", Journal of Econometrics, Elsevier, 142(2): 698-714.

Nichols, A. (2007), "Causal Inference with Observational Data”, Stata Journal, 7(4): 507-541.

Parker, S. and G. Teruel (2005), "Randomization and Social Program Evaluation: the Case of PROGRESA", Annals of the American Academy of Political and Social Science, 599, No.1.

Rawlings (2005), “A New Approach to Social Assistance: Latin America's Experience with Conditional Cash Transfer Programmes", International Social Security Review, 58(2-3):133-161.

Rawlings, L. and G. Rubio (2003), "Evaluating the Impact of Conditional Cash Transfer Programs". World Bank Policy Research Working Paper, 3119.

Rosenbaun, P. and D. Rubin (1983), "The Central Role of the Propensity Score in Observational Studies for Causal Effects", Biometrika 70(1):41-55.

Schultz, T.P., (2004), "School Subsidies for the Poor: Evaluating the Mexican Progresa Poverty Program", Journal of Development Economics, 74(1):199-250.

Skoufias, E. and V. di Maro (2006), "Conditional Cash Transfers, Adult Work Incentives, and Poverty". World Bank Policy Research Working Paper 3973.

Skoufias, E. and Parker, S.W. (2001): "Conditional Cash Transfers and their Impact on Child Work and Schooling: Evidence from the PROGRESA Program in Mexico", Economia, 2(1):45-96. 


\section{APÉNDICE}

\section{A) Discontinuity Test}

TABLE A. 1

DISCONTINUITY TEST

(2006)

\begin{tabular}{lcccccc}
\hline \multirow{2}{*}{ Region } & \multirow{2}{*}{ Observations } & Bandwidth & Binsize & $\begin{array}{c}\text { Discontinuity } \\
\text { estimator }\end{array}$ & $\begin{array}{c}\text { Estimated } \\
\text { standard error }\end{array}$ & It-ratiol \\
\hline Montevideo & 2,006 & 0.18 & 0.01 & 0.08 & 0.13 & 0.62 \\
& & 0.09 & 0.01 & 0.17 & 0.17 & 1.00 \\
& & 0.17 & 0.00 & 0.08 & 0.13 & 0.62 \\
& & 0.09 & 0.00 & 0.15 & 0.18 & 0.83 \\
\hline North & \multirow{2}{*}{1,308} & 0.08 & 0.01 & 0.37 & 0.18 & 2.06 \\
& & 0.05 & 0.01 & 0.12 & 0.23 & 0.52 \\
& & 0.08 & 0.00 & 0.39 & 0.17 & 2.29 \\
North center & 2,101 & 0.05 & 0.00 & 0.15 & 0.23 & 0.65 \\
& & 0.07 & 0.00 & -0.36 & 0.11 & 3.27 \\
& & 0.04 & 0.00 & -0.12 & 0.16 & 0.75 \\
& & 0.08 & 0.00 & -0.42 & 0.11 & 3.82 \\
South center & 0.04 & 0.00 & -0.1 & 0.16 & 0.63 \\
& \multirow{2}{*}{902} & 0.07 & 0.01 & 0.19 & 0.19 & 1.00 \\
& & 0.04 & 0.01 & 0.19 & 0.25 & 0.76 \\
& & 0.07 & 0.00 & 0.22 & 0.19 & 1.16 \\
& & 0.04 & 0.00 & 0.2 & 0.25 & 0.8 \\
\hline South & 1,298 & 0.07 & 0.01 & 0.01 & 0.18 & 0.06 \\
& & 0.04 & 0.01 & -0.03 & 0.27 & 0.11 \\
& & 0.07 & 0.00 & 0.01 & 0.18 & 0.06 \\
& 0.04 & 0.00 & -0.03 & 0.26 & 0.12 \\
\hline
\end{tabular}

Source: Own estimations based on the ECH 2006.

Notes: Standard error in parenthesis. Bootstrap standard error based on 1000 replications, *,** statistically different from zero at $5 \%$ and $1 \%$ respectively. 


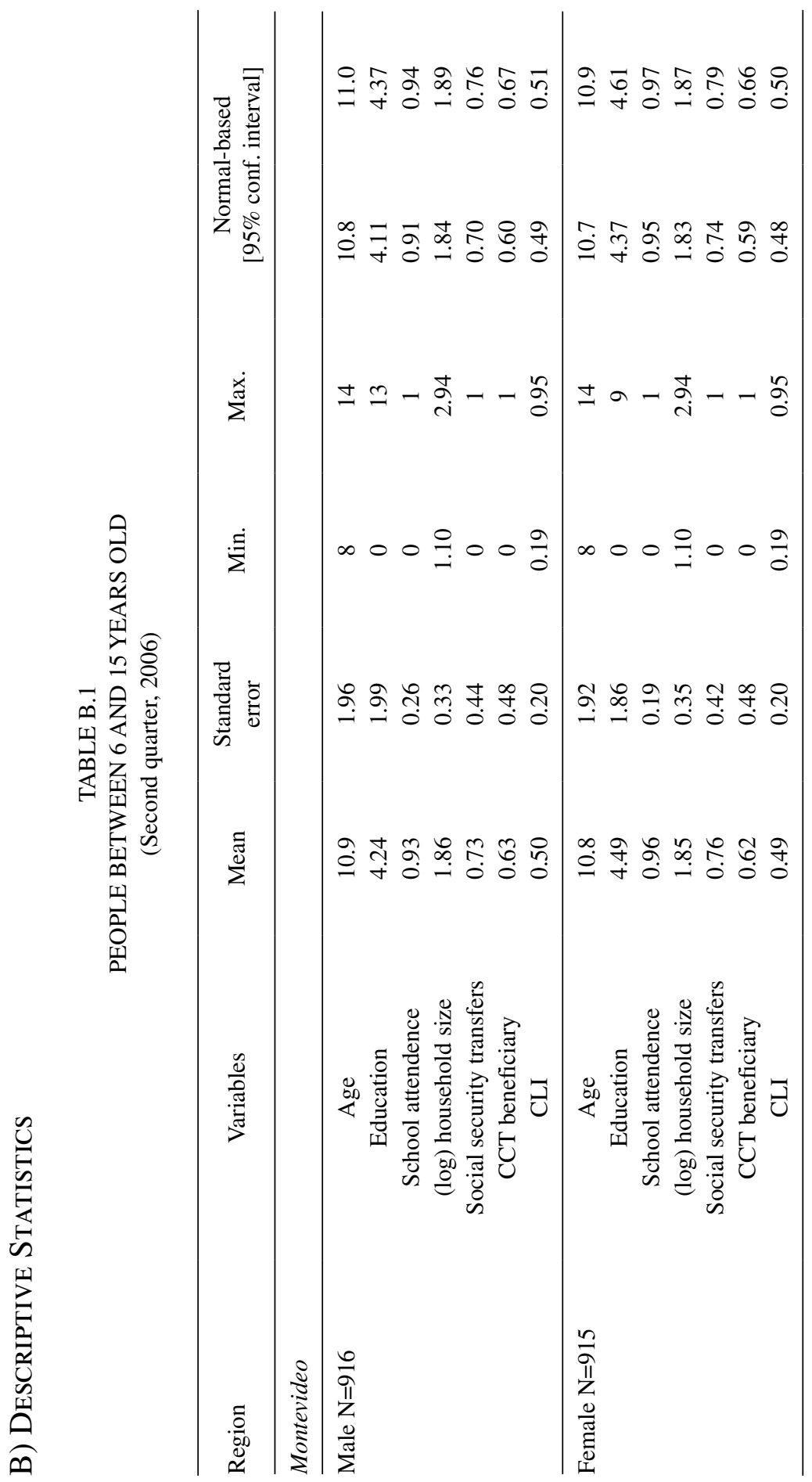




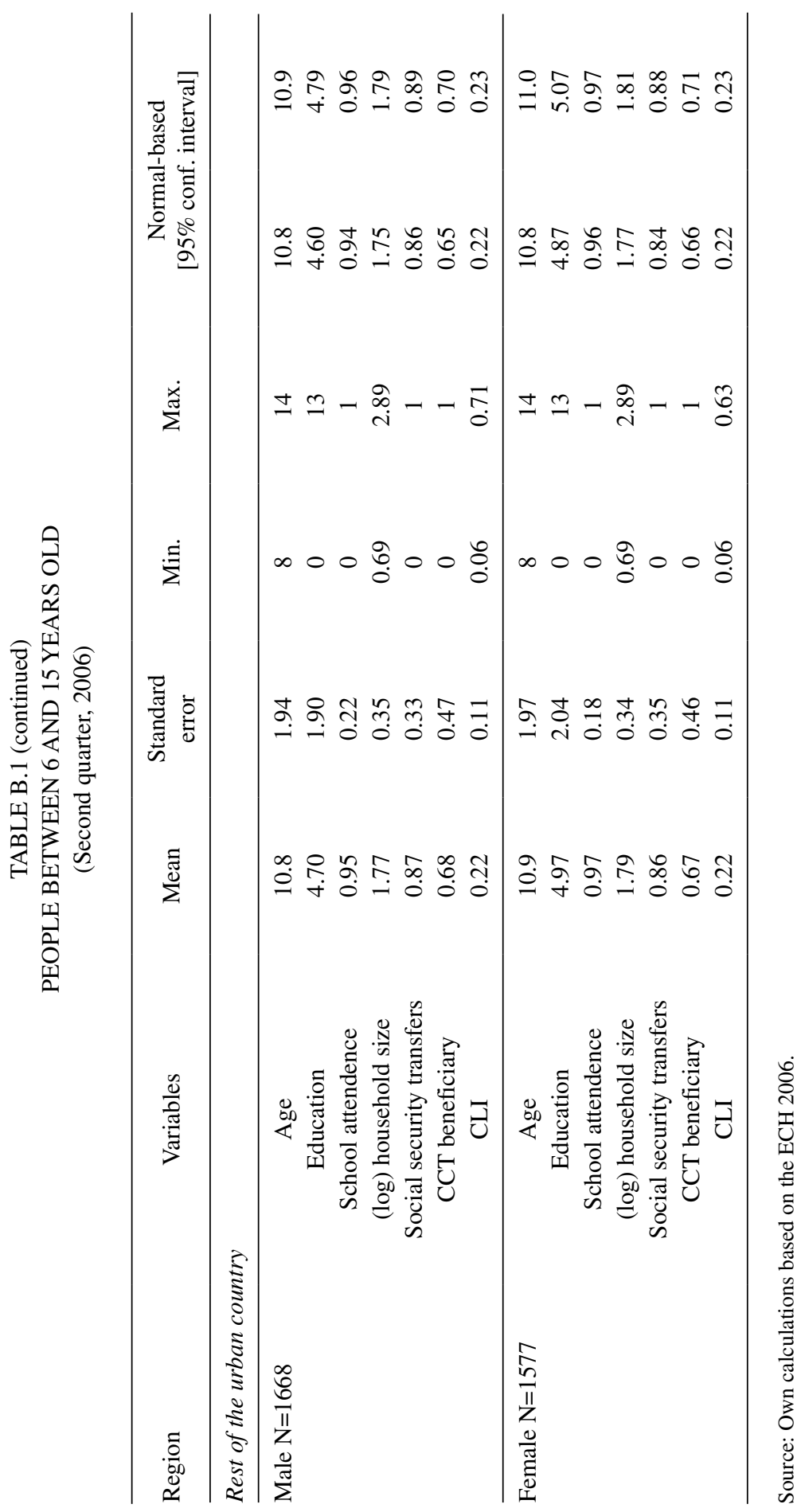




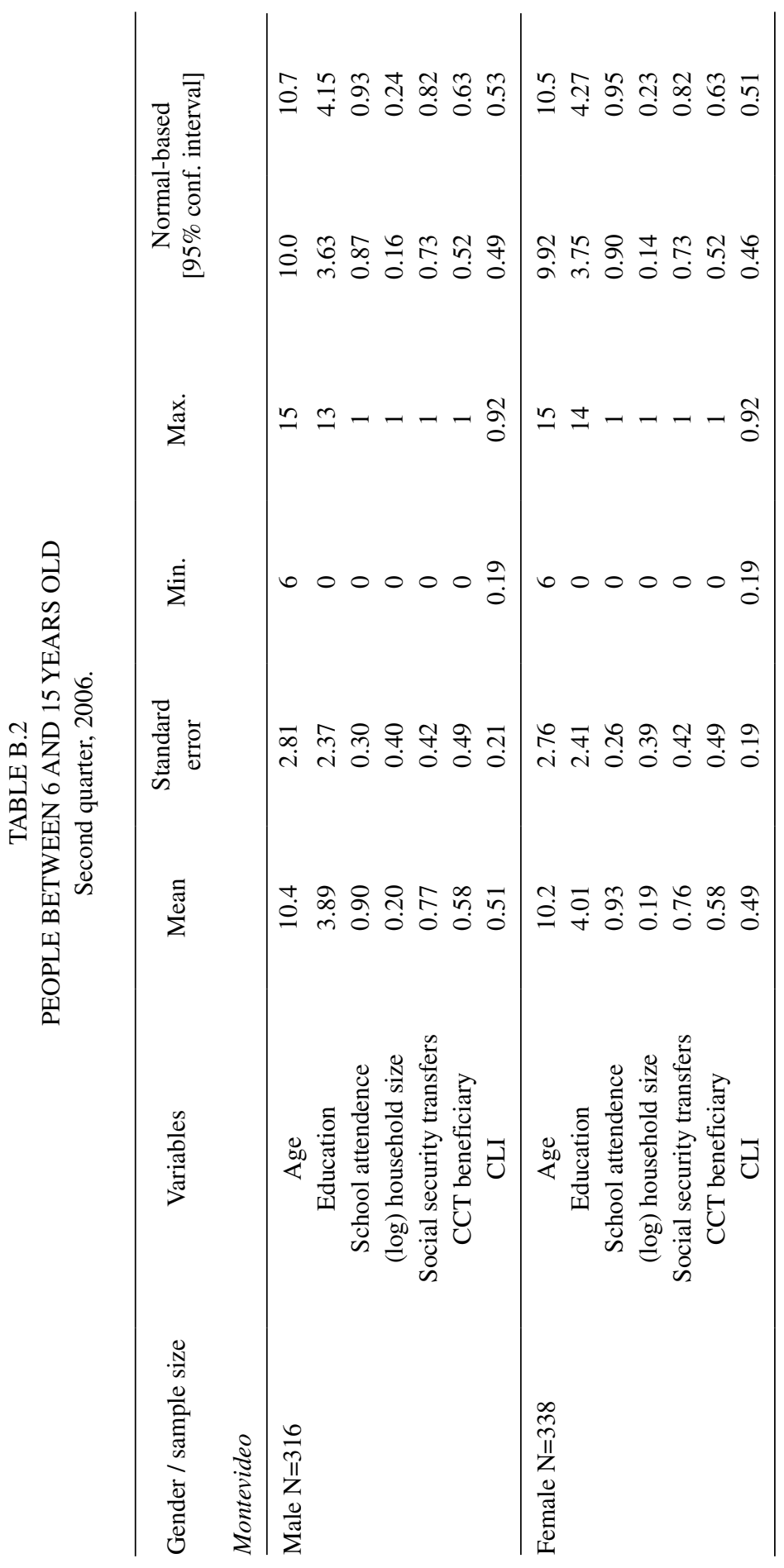




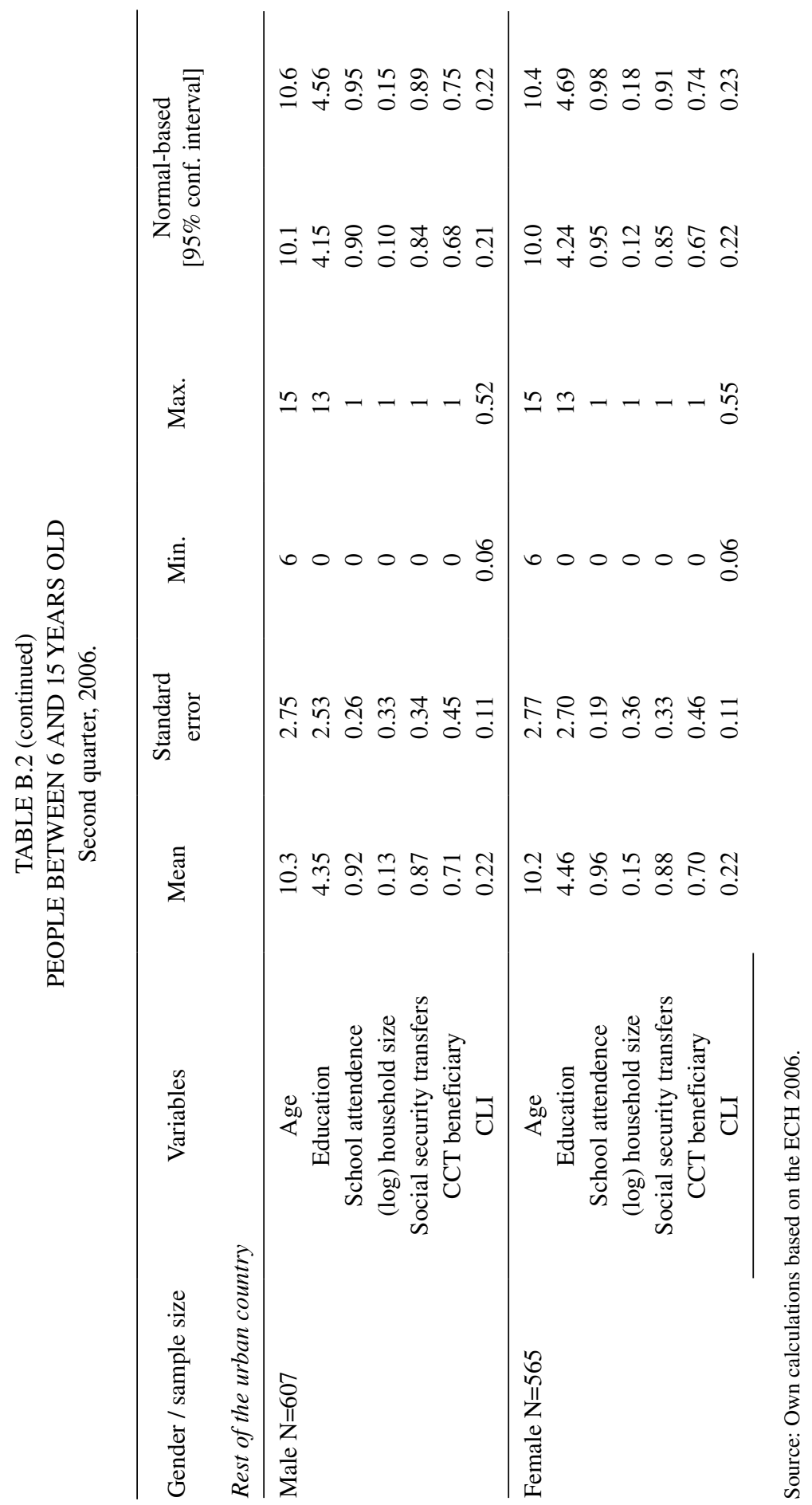




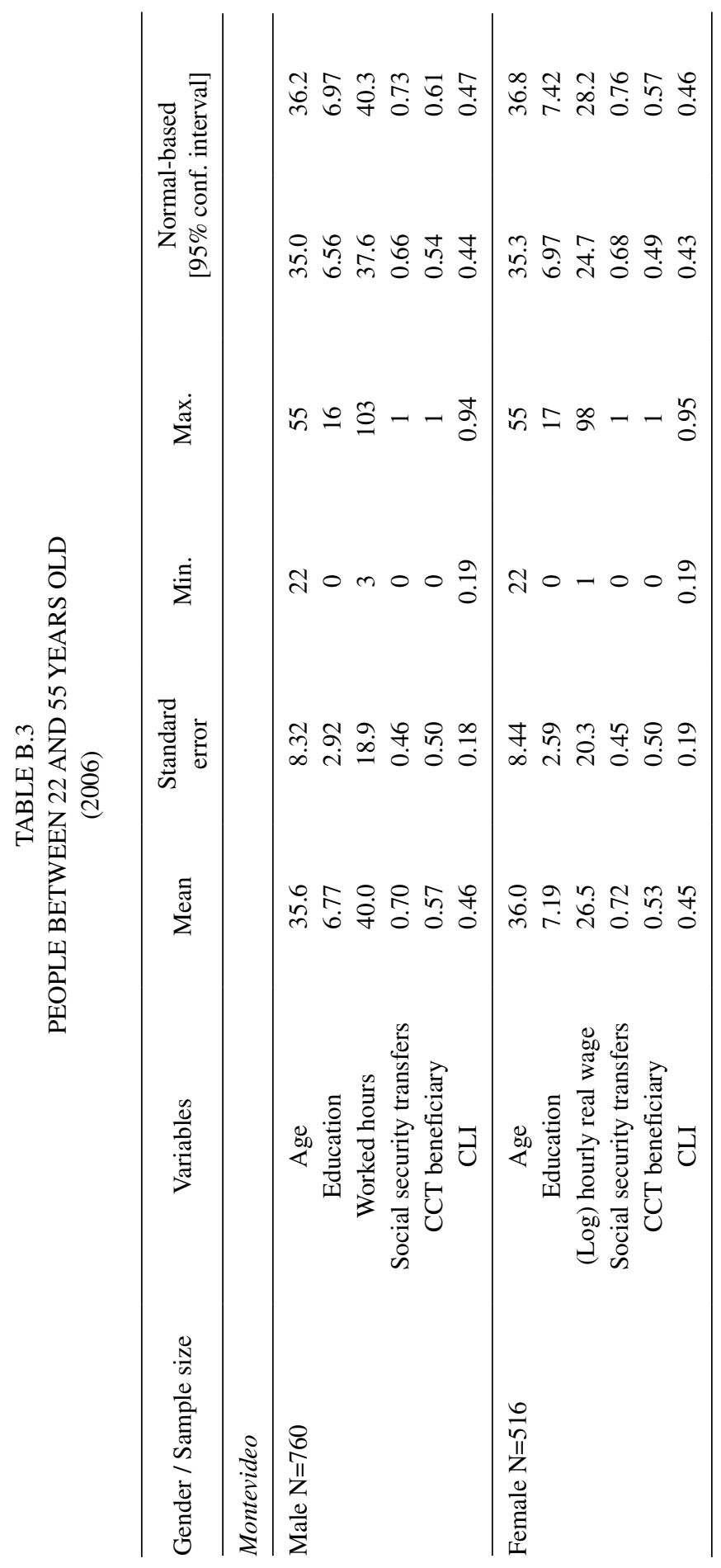




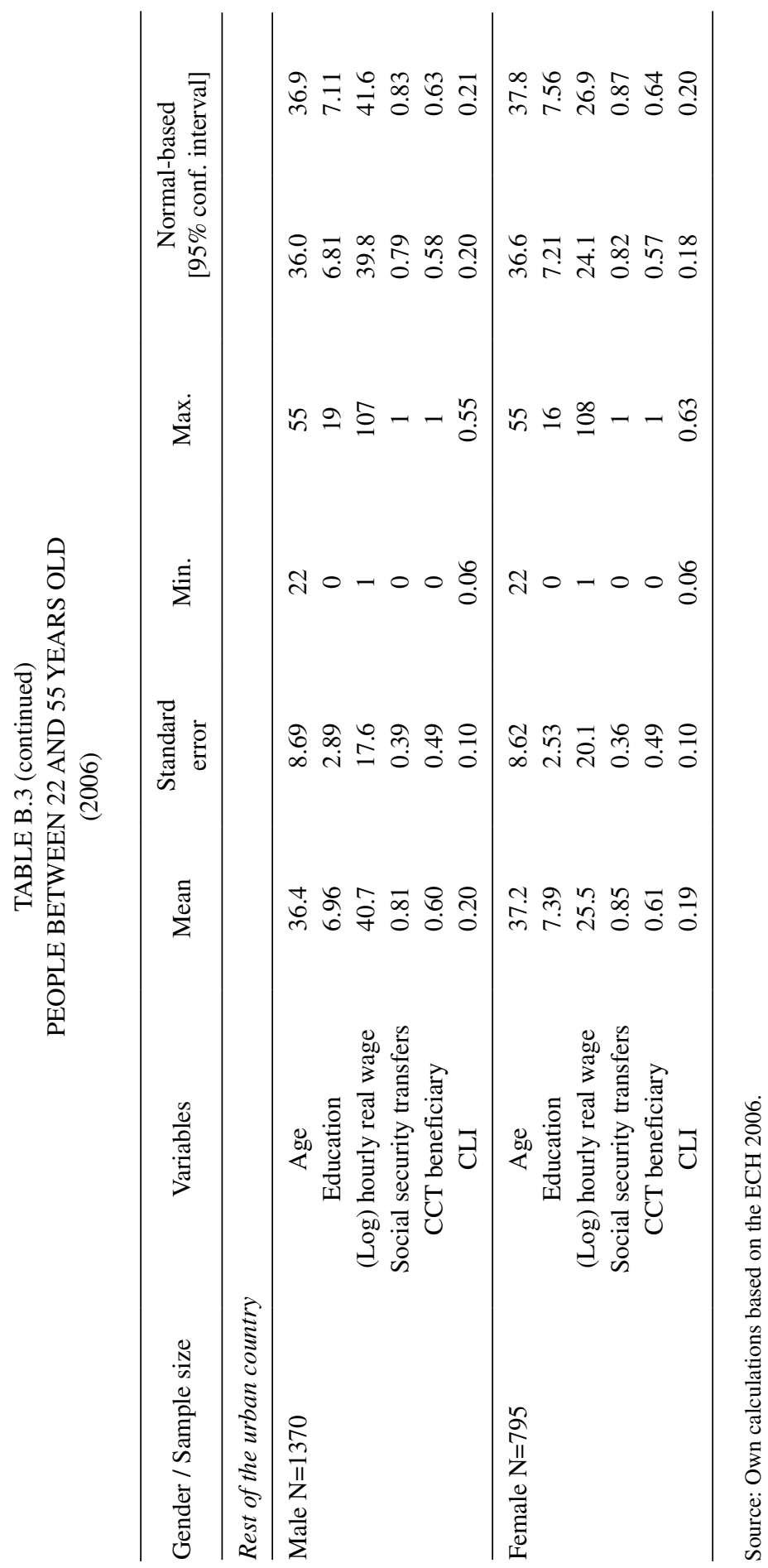




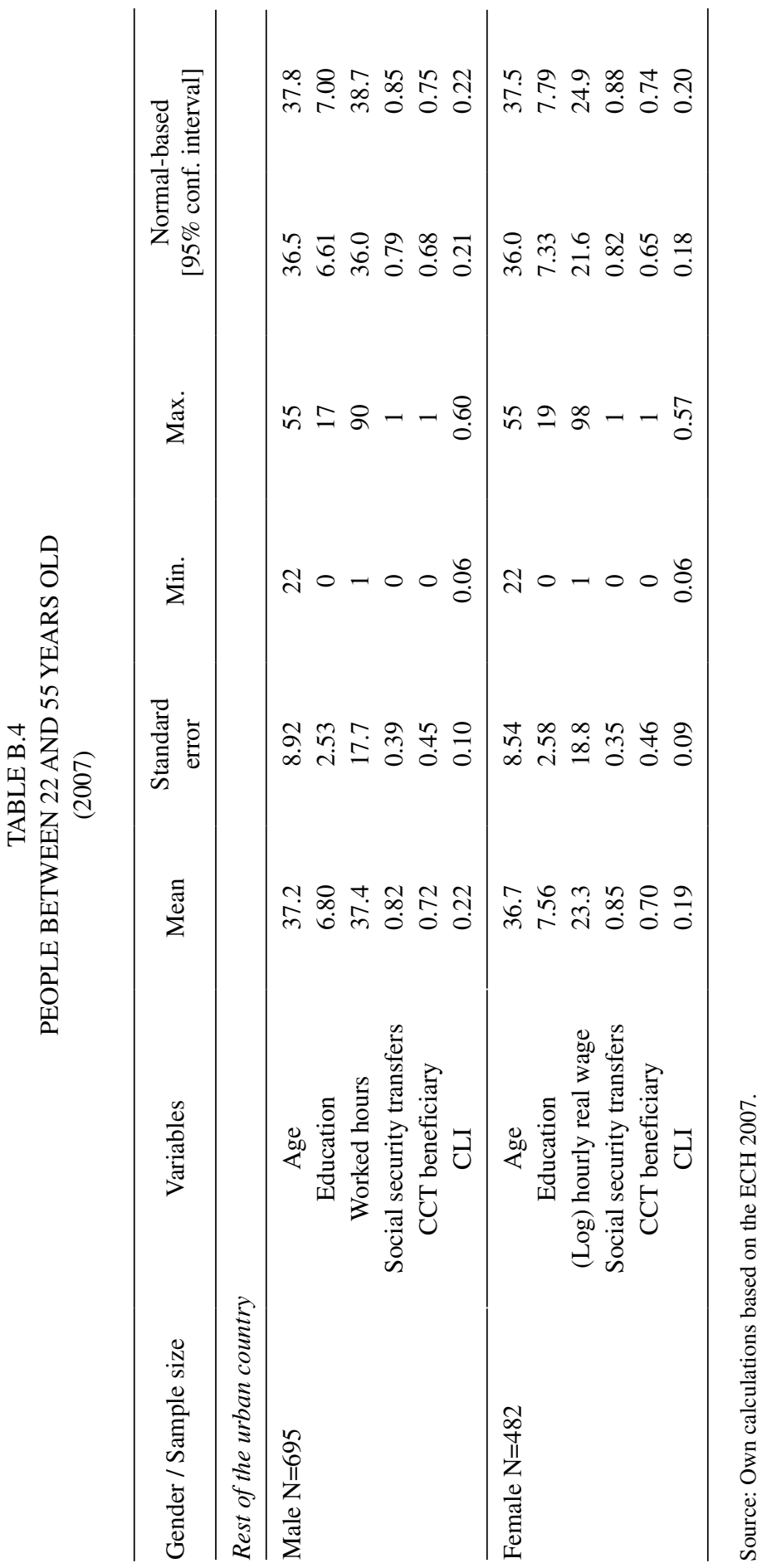

